\title{
Relative importance of fisheries, trophodynamic and environmental drivers in a series of marine ecosystems
}

\author{
Caihong Fu ${ }^{1, *}$, Sarah Gaichas ${ }^{2}$, Jason S. Link ${ }^{3}$, Alida Bundy ${ }^{4}$, Jennifer L. Boldt' ${ }^{1}$, \\ Adam M. Cook ${ }^{4}$, Robert Gamble ${ }^{3}$, Kjell Rong Utne ${ }^{5}$, Hui Liu ${ }^{3}$, Kevin D. Friedland ${ }^{6}$ \\ ${ }^{1}$ Fisheries and Oceans Canada, Pacific Biological Station, Nanaimo, British Columbia V9T 6N7, Canada \\ ${ }^{2}$ NOAA, National Marine Fisheries Service, Alaska Fisheries Science Center, Seattle, Washington 98115, USA \\ ${ }^{3}$ NOAA, National Marine Fisheries Service, Northeast Fisheries Science Center, Woods Hole, Massachusetts 02543, USA \\ ${ }^{4}$ Fisheries and Oceans Canada, Bedford Institute of Oceanography, Dartmouth, Nova Scotia B2Y 4A2, Canada \\ ${ }^{5}$ Institute of Marine Research, Nordnesgt 33, 5085 Bergen, Norway \\ ${ }^{6}$ NOAA, National Marine Fisheries Service, Northeast Fisheries Science Center, Narragansett, Rhode Island 02882, USA
}

\begin{abstract}
Marine ecosystems are influenced by drivers that operate and interact over multiple scales, resulting in nonlinear or abrupt responses to perturbation. Because of the inherent complexity of marine ecosystems, progress towards an understanding of factors that affect fisheries production will be most efficient if researchers adopt a comparative approach across ecosystems using suites of indicators. The goals of this study were to explore a suite of biomass- and catchbased ecosystem response indicators for 9 northern hemisphere ecosystems relative to indices that capture the influence of fisheries, trophodynamic and environmental drivers, and to compare the relative influence of the triad of drivers. Partial least squares regression was used to explore relationships between the ecosystem response indicators and predictor drivers and to estimate the relative importance of each of the triad of drivers. Across ecosystems we have identified a few common observations: (1) environmental drivers, particularly temperature-related independent variables, are most likely related to total system biomass and biomass of specific biological groups (e.g. gadoid or clupeid fishes); (2) trophodynamic drivers are most relevant to the mean trophic level of community and the demersal-to-pelagic biomass ratio; and (3) fisheries drivers tend to be related to the catch-based indicators, such as fishing-in-balance and percent of primary production required to support fisheries. Overall, each of the triad of drivers was important for all ecosystems; however, the relative importance of each driver and the indicators they most affected varied among ecosystems, suggesting that an examination of a suite of indicators and drivers is required. A key finding is that fishing is categorically an important driver, but to explain biomass trends it is very important to consider environmental drivers as well.
\end{abstract}

KEY WORDS: Marine ecosystems - Ecosystem indicators - Partial least squares regression · Multiple drivers

Resale or republication not permitted without written consent of the publisher

\section{INTRODUCTION}

Living marine resources, particularly those targeted by fisheries, are affected by a triad of drivers: anthropogenic (fisheries), trophodynamic and environmental processes. The interactions of these multi- ple drivers are complex and are often manifested in nonlinear responses of ecosystems to perturbation (e.g. Hare \& Mantua 2000, Scheffer \& Carpenter 2003, Steele 2004). These responses put greater demands on management systems for living marine resources, creating a need for more holistic approaches that 
incorporate multiple species in the ecosystem models and account for multiple drivers. The evaluation of new management systems must also move beyond single-species oriented evaluation based solely on performance of commercial fisheries to become more comprehensive. In an ecosystem context, measures of 'success' of management strategies beyond the human dimension of benefits and trade-offs should be included to evaluate the ability to maintain ecosystem stability and resistance to perturbation, and to maintain ecosystem structure and functioning and sustainability of resource potential (Shin et al. 2010b). These types of measures, known as ecosystem indicators, have received increasing attention in recent years (e.g. Cury \& Christensen 2005, Shin \& Shannon 2010, Shin et al. 2010a,b).

Ecosystem indicators are generally accepted as tools for evaluating ecosystem status and trends (e.g. Shin \& Shannon 2010, Shin et al. 2010a,b), identifying key ecosystem processes (e.g. Ojaveer \& Eero 2011), serving as signals that something is happening beyond what is actually measured (NRC 2000), and assessing the impacts of human activities and climate forcing (e.g. Coll et al. 2010, Link et al. 2010b, Ojaveer \& Eero 2011). Hundreds of potential ecosystem indicators exist, including environmental, species-based, size-based, trophodynamic and integrated indicators (Cury \& Christensen 2005). For example, indicators available for the Northeast US Continental shelf ecosystem include 26 biotic state indicators, 25 indicators of climate and physical environmental change and 18 indicators of human-driven pressure on the ecosystem (Ecosystem Assessment Program 2009). Similarly, information on 59 physical, biological and ecological status and trend indicators and 14 ecosystem-based management indicators are available for US marine ecosystems off Alaska (Zador 2011). For a particular study, a suite of indicators needs to be selected to reflect human activities, ecosystem components and ecosystem attributes (e.g. Jennings 2005, Piet et al. 2008). In this study, we select a suite of indicators to compare ecosystem responses to a triad of external drivers across 9 northern hemisphere ecosystems. The suite of indicators is derived from standard fisheries-independent survey data and fisheries-dependent catch data (e.g. Pauly \& Christensen 1995, Christensen 2000, Cury \& Christensen 2005, Shin et al. 2010a,b). The triad of drivers considered encompasses fisheries exploitation, trophodynamic interactions and local- and basin-scale environmental factors.

Our objective is to infer cause-effect relationships by examining linkages between the suite of indictors and the triad of drivers. Multiple regression analysis is often applied in this type of investigation (Carrascal et al. 2009), which works well as long as the predictor variables are fairly few and uncorrelated. For instance, Blanchard et al. (2005) used multiple linear regression to relate ecosystem indicators to fishing and temperature drivers. However, the traditional regression approach poses problems when it comes to handling multivariate predictor variables that are correlated and have redundancies. To overcome this problem, researchers often preselect a few predictor variables that are independent based on expert knowledge; however, this process can unknowingly screen out potentially important predictor variables. Another limitation of the traditional regression approach is that it does not allow multiple response variables to be considered at the same time. Just as body condition can be measured in several ways, and health should be assessed as a combination of the several measurements, marine ecosystem condition and health should be investigated using a combination of indicators that reflect different aspects of the ecosystem structure and functioning (Link 2005, 2010). A more inclusive practice is to use multivariate reduction methods such as principal component analysis to derive independent principal components, which are then used in subsequent multiple regression analyses (Wold et al. 2001). However, the derived principal components maximize the covariation among the predictor variables independent of the variation in the response variables and thus they are not likely to be the good predictors for the response variables.

In this study, the ecosystem indicators and the triad of drivers were explored as response and predictor variables, respectively, using partial least squares (PLS) regression, an ideal statistical tool for inferring probable cause-effect interactions between response and predictor variables that overcomes the limitations of the traditional regression approach stated above. Although the application of PLS regression in ecological studies has been uncommon (Carrascal et al. 2009), there is great potential for the use of PLS regression given its properties, and there are a few recent applications of this approach in the field of marine fishery science (e.g. Wells et al. 2008, Friedland et al. 2012). Because marine ecosystems are inherently complex, adopting a comparative approach will expedite the understanding of factors that affect fisheries production (Link et al. 2010a); in particular, comparisons of ecosystem indicators across different ecosystems advance the understanding of ecosystem structure, functioning and state 
(Coll et al. 2010, Shannon et al. 2010, Shin et al. 2010b). Such indicator-based comparisons allow contrasts in the structure and functioning of the ecosystems related to their intrinsic features and exploitation history to be developed (Coll et al. 2006). Through multivariate and comparative analysis, we aim to explore the effects of common drivers on ecosystem indicators at the basin scale, compare the relative influence within the triad of drivers among ecosystems and explore the connections between fishing and environmental variability.

\section{MATERIALS AND METHODS}

\section{Ecosystems and data sets}

The 9 northern hemisphere ecosystems we explored are the eastern Bering Sea, Gulf of Alaska and Hecate Strait in the Pacific Ocean, and the Barents/ Norwegian Seas, southern Gulf of St. Lawrence, eastern Scotian Shelf, western Scotian Shelf, Gulf of Maine and Georges Bank in the Atlantic Ocean (see Fig. 2 in Link et al. 2012, this Theme Section). These ecosystems have varied species composition, fishery exploitation histories and environmental influences. A summary of key characteristics of these ecosystems is listed in the supplement (www.int-res.com/articles/ suppl/m459p169_supp.pdf). In order to calculate indicators, annual survey biomass and catch time series for the period from 1984 to 2006 were compiled for the 9 ecosystems. The number of species that provided time series data in each ecosystem is given in Table 1. Each species within an ecosystem was then assigned to a specific ecological group based on habitat (demersal and pelagic), feeding guild (planktivore, zoopivore (shrimp and/or euphausiid eater), benthivore, piscivore and omnivore), or taxonomic grouping (clupeid, elasmobranch, pleuronectid, gadoid, Sebastes, invertebrates, forage fish and mammals). The trophic level for each species was also obtained either from Ecopath models, if available, or from Fishbase (Froese \& Pauly 2011). The trophodynamic and environmental drivers for each system used as predictors in the PLS regression were selected by regional experts who were asked to identify those regional and basin-scale variables that are generally considered to be important drivers of productivity in a given ecosystem (Bundy et al. 2012, Table S2 in their supplement). Available biotic and abiotic time series data compiled for each system included abundance indices of zooplankton and important top-level predators, water temperature, stratification, large-scale cli- mate indices and freshwater discharge (Table 1). All the biomass, catch and trophodynamic and environmental drivers were compiled into a common database for use in this and other comparative studies of fishery production (Link et al. 2010a).

\section{Ecosystem response indicators}

Many ecosystem indicators have been proposed to describe ecosystem status and detect fishing effects on ecosystems (e.g. Fulton et al. 2005, Jennings 2005, Link 2005). Here we have focused on a few common ecological indicators derived from survey biomass and catch data, following to some extent the approach of the IndiSeas Project (Shin et al. 2010a). Annual data points from these time series were used as response variables in PLS regression.

We explored 2 common biomass-based indicators: total biomass $(B)$ to indicate ecosystem status, and proportion of predatory fish $(\% \operatorname{pred} B)$ to measure functional diversity of fish in the community and reflect the potential effects of fishing on the functioning of marine food webs (Shin et al. 2010a). In addition, the demersal-to-pelagic fish biomass ratio $(D / P)$ was calculated as an indicator of the processes leading to demersal or pelagic energy pathways (Coll et al. 2010). Biomasses of clupeids ( $\left.B_{\text {clupeid }}\right)$ and gadoids $\left(B_{\text {gadoid }}\right)$ were used as 2 indicators reflecting temporal dynamics of these 2 fish groups, which are represented in all of the ecosystems we compared. We also calculated the mean trophic level of the community (mTLco) based on trophic levels (TL) of all species with available biomass time series, weighted by annual species-specific biomass, to reflect the structure of the community.

For catch-based time series indicators, exploitation rate (denoted as $F^{\prime}$ ) was calculated as the ratio of total catch to total biomass in each year aggregated over the same set of species. In addition, we used 3 other commonly used catch-based quantities as response indicators: the mean trophic level of the catch (mTLc), primary production required to sustain fisheries (Pauly \& Christensen 1995) and the fishing-inbalance index (Christensen 2000). The mean trophic level of the catch is calculated as the weighted average trophic level of all species included in the catch data, thereby reflecting the fishing strategy in terms of its species selection (Christensen \& Walters 2004). The primary production required (PPR) indicator is an estimate of the amount of primary production required to support fishery catch. PPR expresses the full ecosystem 'cost' of fisheries and is given by: 
Table 1. Number of species in biomass and catch data and trophodynamic and environmental drivers available in 9 ecosystems

\begin{tabular}{|c|c|c|c|c|c|c|c|c|}
\hline \multicolumn{2}{|c|}{ No. species } & \multicolumn{7}{|c|}{ - Trophodynamic and environment drivers } \\
\hline $\begin{array}{c}\text { In } \\
\text { biomas }\end{array}$ & $\begin{array}{l}\text { In } \\
\text { catch }\end{array}$ & 1 & 2 & 3 & 4 & 5 & 6 & 7 \\
\hline \multicolumn{9}{|c|}{ Eastern Bering Sea } \\
\hline 58 & 14 & $\begin{array}{c}\text { Bcope: } \\
\text { abundance } \\
\text { index of } \\
\text { copepods }\end{array}$ & $\begin{array}{c}\text { sSST: } \\
\text { summer } \\
\text { average } \\
\text { surface water } \\
\text { temperature }\end{array}$ & $\begin{array}{l}\text { ice: } \\
\text { ice cover } \\
\text { index }\end{array}$ & $\begin{array}{c}\text { ONI: } \\
\text { oceanic Niño } \\
\text { index }\end{array}$ & $\begin{array}{l}\text { NPI: } \\
\text { North Pacific } \\
\text { index }\end{array}$ & $\begin{array}{c}\text { ALPI: } \\
\text { Aleutian low } \\
\text { pressure } \\
\text { index }\end{array}$ & $\begin{array}{c}\text { PDO: } \\
\text { Pacific } \\
\text { Decadal } \\
\text { Oscillation }\end{array}$ \\
\hline \multicolumn{9}{|c|}{ Gulf of Alaska } \\
\hline 42 & 22 & $\begin{array}{c}\text { sSST: } \\
\text { summer } \\
\text { average } \\
\text { surface water } \\
\text { temperature }\end{array}$ & $\begin{array}{c}\text { discharge: } \\
\text { April } \\
\text { freshwater } \\
\text { discharge }\end{array}$ & $\begin{array}{l}\text { ONI: oceanic } \\
\text { Niño index }\end{array}$ & $\begin{array}{l}\text { NPI: North } \\
\text { Pacific index }\end{array}$ & $\begin{array}{c}\text { ALPI: } \\
\text { Aleutian low } \\
\text { pressure index }\end{array}$ & $\begin{array}{c}\text { PDO: } \\
\text { Pacific } \\
\text { Decadal } \\
\text { Oscillation }\end{array}$ & \\
\hline \multicolumn{9}{|c|}{ Hecate Strait } \\
\hline 30 & 25 & $\begin{array}{c}\text { Bafl: } \\
\text { biomass index } \\
\text { of arrowtooth } \\
\text { flounder } \\
\text { Atheresthes } \\
\text { stomias }\end{array}$ & $\begin{array}{c}\text { wSST: } \\
\text { winter } \\
\text { average } \\
\text { surface water } \\
\text { temperature }\end{array}$ & $\begin{array}{c}\text { wSSH: } \\
\text { winter sea } \\
\text { surface height }\end{array}$ & $\begin{array}{l}\text { ONI: } \\
\text { oceanic Niño } \\
\text { index }\end{array}$ & $\begin{array}{l}\text { NPI: } \\
\text { North Pacific } \\
\text { index }\end{array}$ & $\begin{array}{c}\text { ALPI: } \\
\text { Aleutian low } \\
\text { pressure } \\
\text { index }\end{array}$ & $\begin{array}{c}\text { PDO: } \\
\text { Pacific } \\
\text { Decadal } \\
\text { Oscillation }\end{array}$ \\
\hline \multicolumn{9}{|c|}{ Barents/Norwegian seas } \\
\hline 8 & 11 & $\begin{array}{c}\text { Bzoo: } \\
\text { abundance } \\
\text { index of } \\
\text { zooplankton }\end{array}$ & $\begin{array}{c}\text { Bseal: } \\
\text { biomass index } \\
\text { of harp seal } \\
\text { Phoca } \\
\text { groenlandica }\end{array}$ & $\begin{array}{c}\text { BS_SST: } \\
\text { annual average } \\
\text { surface water } \\
\text { temperature in } \\
\text { Barents Sea }\end{array}$ & $\begin{array}{c}\text { NS_SST: } \\
\text { annual average } \\
\text { surface water } \\
\text { temperature in } \\
\text { Norwegian Sea }\end{array}$ & $\begin{array}{l}\text { ice: } \\
\text { ice cover } \\
\text { index }\end{array}$ & $\begin{array}{l}\text { NAO: } \\
\text { North Atlantic } \\
\text { Oscillation } \\
\text { index }\end{array}$ & \\
\hline \multicolumn{9}{|c|}{ Southern Gulf of St. Lawrence } \\
\hline 36 & 29 & $\begin{array}{c}\text { Bszoo: } \\
\text { abundance } \\
\text { index of small } \\
\text { zooplankton }\end{array}$ & $\begin{array}{c}\text { Blzoo: } \\
\text { abundance } \\
\text { index of large } \\
\text { zooplankton }\end{array}$ & $\begin{array}{c}\text { Bseal: } \\
\text { biomass index } \\
\text { of grey seal } \\
\text { Halichoerus } \\
\text { grypus }\end{array}$ & $\begin{array}{c}\text { SST: } \\
\text { annual average } \\
\text { surface water } \\
\text { temperature }\end{array}$ & $\begin{array}{c}90 \mathrm{mT}: \\
\text { fall average } \\
\text { water } \\
\text { temperature } \\
\text { at } 60-120 \mathrm{~m}\end{array}$ & & \\
\hline \multicolumn{9}{|c|}{ Eastern Scotian Shelf } \\
\hline 42 & 74 & $\begin{array}{c}\text { Bseal: } \\
\text { biomass index } \\
\text { of grey seal }\end{array}$ & $\begin{array}{l}\text { SST: annual } \\
\text { average } \\
\text { surface water } \\
\text { temperature }\end{array}$ & $\begin{array}{c}\text { sBT: } \\
\text { summer average } \\
\text { water tempera- } \\
\text { ture at bottom }\end{array}$ & $\begin{array}{c}50 \mathrm{mT}: \\
\text { annual average } \\
\text { water tempera- } \\
\text { ture at } 50 \mathrm{~m}\end{array}$ & $\begin{array}{c}100 \mathrm{mT}: \\
\text { annual average } \\
\text { water tempera- } \\
\text { ture at } 100 \mathrm{~m}\end{array}$ & $\begin{array}{c}\text { strat: } \\
\text { index of } \\
\text { stratification }\end{array}$ & \\
\hline \multicolumn{9}{|c|}{ Western Scotian Shelf } \\
\hline 33 & 29 & $\begin{array}{c}\text { SST: } \\
\text { annual } \\
\text { average } \\
\text { surface water } \\
\text { temperature }\end{array}$ & $\begin{array}{c}\text { sBT: } \\
\text { summer } \\
\text { average water } \\
\text { temperature at } \\
\text { bottom }\end{array}$ & $\begin{array}{c}50 \mathrm{mT}: \\
\text { annual average } \\
\text { water tempera- } \\
\text { ture at } 50 \mathrm{~m}\end{array}$ & $\begin{array}{c}100 \mathrm{mT}: \\
\text { annual average } \\
\text { water tempera- } \\
\text { ture at } 100 \mathrm{~m}\end{array}$ & $\begin{array}{c}\text { strat: } \\
\text { index of } \\
\text { stratification }\end{array}$ & $\begin{array}{l}\text { BoFstrat: } \\
\text { index of } \\
\text { stratification, } \\
\text { Bay of Fundy }\end{array}$ & \\
\hline \multicolumn{9}{|c|}{ Gulf of Maine } \\
\hline 27 & 25 & $\begin{array}{c}\text { Bzoo: } \\
\text { abundance } \\
\text { index of } \\
\text { zooplankton }\end{array}$ & $\begin{array}{c}\text { SST: } \\
\text { average } \\
\text { annual surface } \\
\text { temperature }\end{array}$ & $\begin{array}{c}\text { NAO: } \\
\text { North Atlantic } \\
\text { Oscillation }\end{array}$ & $\begin{array}{c}\text { AMO: } \\
\text { Atlantic } \\
\text { Multidecadal } \\
\text { Oscillation }\end{array}$ & & & \\
\hline \multicolumn{9}{|c|}{ Georges Bank } \\
\hline 28 & 26 & $\begin{array}{c}\text { Bzoo: } \\
\text { abundance } \\
\text { index of } \\
\text { zooplankton }\end{array}$ & $\begin{array}{c}\text { SST: } \\
\text { average } \\
\text { annual surface } \\
\text { temperature }\end{array}$ & $\begin{array}{c}\text { NAO: } \\
\text { North Atlantic } \\
\text { Oscillation }\end{array}$ & $\begin{array}{c}\text { AMO: } \\
\text { Atlantic } \\
\text { Multidecadal } \\
\text { Oscillation }\end{array}$ & & & \\
\hline
\end{tabular}




$$
\mathrm{PPR}=\frac{1}{9} \cdot \sum_{i}\left[Y_{i}(\mathrm{TE})^{\mathrm{TL}_{i}-1}\right]
$$

where $Y_{i}$ is the catch of a given species (or group) $i_{\text {, }}$ $\mathrm{TL}_{i}$ is the trophic level of the species $i$ and factor $1 / 9$ is the average conversion coefficient from wet weight to grams of carbon. The constant term TE is the mean energy-transfer efficiency between trophic levels, and the average TE value of 14 for temperate shelves and seas (Libralato et al. 2008) was used for each ecosystem. For comparative purposes, the PPR for each system was scaled by dividing by primary production $\left(P_{1}\right)$ estimated from Sea-viewing Wide Field-of-view Sensor (SeaWiFS) data (Behrenfeld \& Falkowski 1997) and averaged over the period from 1998 to 2008 , to obtain the percent of primary production required $\left(\% \mathrm{PPR}=\mathrm{PPR} / P_{1}\right)$. For a given $\% \mathrm{PPR}$, a fishery with higher TL would have less impact than a fishery with a lower TL owing to the much lower catch; however, for a given TL, a lower \%PPR would have less impact than one with a higher \%PPR, since the removals would be higher (Tudela et al. 2005).

The fishing-in-balance (FIB) index describes the changes in the primary production required by fisheries over time relative to the initial year (Christensen 2000), and is formulated as:

$$
F I B=\ln \left[\frac{\sum_{i} Y_{i t} \cdot \mathrm{TE}^{\mathrm{TL}_{i}-1}}{\sum_{i} Y_{i 0} \cdot \mathrm{TE}^{\mathrm{TL}_{i}-1}}\right]
$$

where $Y_{i t}$ is the catch of species $i$ during the year $t$, $Y_{i 0}$ is the catch of species $i$ during the year at the start of a time series and TE and TL are as defined above. The indicator FIB is intended to capture changes in fishing strategies and their impact on system productivity: a positive FIB index indicates that the fishery has expanded and/or bottom-up effects are occurring, and there is more catch than expected; a negative FIB index indicates it is likely that the fishing impact is so high that the ecosystem function is impaired and the ecosystem is less productive owing to excessive fishery removals (Christensen 2000).

\section{Ecosystem drivers}

We used a suite of drivers (fisheries, trophodynamic and environmental) as predictor variables. Fisheries drivers were all derived from catch time series for each ecosystem, but we examined fishing in the ecosystem context at the level of comparable aggregate groups based on feeding guilds rather than single species. In a few cases we combined related guilds further (e.g. planktivores and zoo- pivores) to avoid zero values in some ecosystems. Therefore, our fishing drivers included catch in weight and percentage of total catch for 3 combinations of different feeding guilds: planktivores and zoopivores (PZ, \%PZ), piscivores and omnivores $(\mathrm{PiO}, \% \mathrm{PiO})$ and benthivores, piscivores and omnivores $(\mathrm{BPiO}, \% \mathrm{BPiO})$. These fishery drivers were considered for each ecosystem as they reflect alternative fishing strategies as well as relative abundance of different feeding guild groups over time.

Trophodynamic drivers included time series generally related to prey and predators of fished species to examine potential bottom-up and top-down effects on fisheries production. A number of studies have reported positive relationships between fish production and primary production (Ware \& Thomson 2005, Chassot et al. 2007, Sherman et al. 2009), although the effectiveness of primary production as a predictor of fishery catch is reduced at the global scale (Friedland et al. 2012). Friedland et al. (2012) found significant correlations between mesozooplankton productivity and fisheries yields. Accordingly, we evaluated ecosystem-specific biomass indices of zooplankton and/or top-level predators as trophodynamic drivers for 7 out of the 9 ecosystems in our analyses (see Table 1 for descriptions of each index).

Environmental drivers generally represented some form of thermal or broad-scale oceanographic features considered to be influential in each ecosystem. We included some measure of sea surface temperature (SST) for all ecosystems, although winter, summer or annual SST indices were applied in different ecosystems. Broad-scale climate indices were applied where appropriate to specific ecosystems, including the North Pacific Index (NPI) and Pacific Decadal Oscillation (PDO) in the Pacific Ocean, and the North Atlantic Oscillation (NAO) and Atlantic Multidecadal Oscillation (AMO) in the Atlantic Ocean (Table 1). Additional environmental variables such as stratification, freshwater discharge and sea ice cover were considered important locally and were therefore included for specific ecosystems, similar to Bundy et al. (2012, their Table S2). Having a different set of trophodynamic and environmental drivers for each ecosystem was appropriate for our statistical analyses, as we analyzed each ecosystem's indicators and drivers independently.

\section{Statistical analyses}

PLS regression is essentially a dimension reduction technique that extracts a few latent variables 
called $X$-scores from predictor matrix $X$ (size: $n \times m$ ) that maximize the explained variance in the response matrix $Y$ (size: $n \times p$ ). The $X$-scores, denoted by matrix $T$ (size: $n \times l$, where $l$ is the number of components), are linear combinations of the matrix $X$ with coefficient matrix $W^{*}$ (size: $m \times 1)$, i.e.

$$
T=X W^{*}
$$

The $X$-scores are predictors of $X$ and also $Y$ (Eqs. 2 \& 3 below); i.e. both $X$ and $Y$ are assumed to be, at least partly (aside from residuals), modeled by the same latent variables:

$$
X=T P+E
$$

and

$$
Y=T Q+F
$$

where $P$ and $Q$ are matrices of coefficients (loadings) with the dimensions of $m \times 1$ and $p \times 1$, respectively, and $E$ and $F$ are residual matrices. For multivariate $Y$ $(p>1)$, they are the combinations of the corresponding $Y$-scores (denoted by $U$ with size: $n \times l$ ) and the loading matrix $Q$ along with a residual matrix $G$ :

$$
Y=U Q+G
$$

Because $T=X W^{*}$, from Eq. (1), Eq. (3) can be rewritten as:

$$
Y=X W^{*} Q+F=X B+F
$$

where $B$ is the coefficient matrix of PLS regression.

All calculations were implemented for each ecosystem independently using packages 'pls', 'plspm', and 'mixOmics' in R (R Development Core Team 2011) for the entire period from 1984 to 2006, a period when both biomass and catch data were available for all ecosystems. Before applying PLS regression, the predictor drivers and ecosystem response indicators were normalized (mean $=0$, $\mathrm{SD}=1$ ) by applying a Z-transformation. For the PLS regression, the first step is to determine the optimal number of components by testing the predictive significance of models with different numbers of components. The root mean squared errors of prediction (RMSEPs) of each ecosystem response indicator were estimated through leave-one-out cross-validation. In addition, the residuals of the ecosystem response indicators were examined for autocorrelations. Once the optimal number of components was determined, the estimates of the regression coefficient of predictor drivers were corrected based on bootstrapped CIs with the coefficient set to zero if the CI contained zero.

\section{RESULTS}

\section{Ecosystem response indicator trends}

Biomass-based ecosystem indicators showed some similar trends across ecosystems and also highlighted some key dynamics within ecosystems. During the period 1984 to 2006, total biomass of the eastern Bering Sea and the eastern and western Scotian Shelf showed slight declines due to the reduction of gadoid biomass in the eastern Bering Sea and eastern Scotian Shelf and clupeid biomass in the western Scotian Shelf. In contrast, the total biomass of the Barents/Norwegian Seas and Gulf of Maine increased steadily due to the increase of gadoid biomass and particularly clupeid biomass (Fig. 1). Despite the slight increase of total biomass, the Gulf of Maine experienced a dramatic decline in the proportion of predatory biomass and in the mean trophic level in the community, implying that the community has become more dominated by species at lower trophic levels. In contrast, the Gulf of Alaska experienced steady increases in the proportion of predator biomass, mean trophic level of the community and the demersal-to-pelagic biomass ratio, despite the fact that total biomass showed no increase over the entire period, indicating increased dominance of higher trophic level species in this ecosystem.

Trends in catch-based ecosystem indicators were more variable across ecosystems, but showed consistency within ecosystems. The overall exploitation rate for the eastern Scotian Shelf declined after the early 1990s, and the exploitation rate in the Gulf of Maine decreased over the entire study period. The exploitation rate in the Barents/Norwegian Seas declined in the late 1980s and was stable afterwards $\left(\sim 0.15 \mathrm{yr}^{-1}\right)$, but there were no clear consistent trends in exploitation rate in the other ecosystems (Fig. 2). The fishing-in-balance indices for southern Gulf of St. Lawrence, eastern Scotian Shelf, western Scotian Shelf, Gulf of Maine and Georges Bank were all negative, indicating high fishing impact. In particular, the fishing-in-balance index of the eastern Scotian Shelf showed a dramatic decline in the early 1990s, suggesting a possible decrease in ecosystem productivity. In contrast, the fishing-in-balance indices for the eastern Bering Sea and Gulf of Alaska were 'balanced', while those of the Barents/Norwegian Seas and Hecate Strait gave positive values with slightly increasing trends. The trajectories of mean trophic level of the catch and the percent primary production required to sustain fisheries were similar to those of 


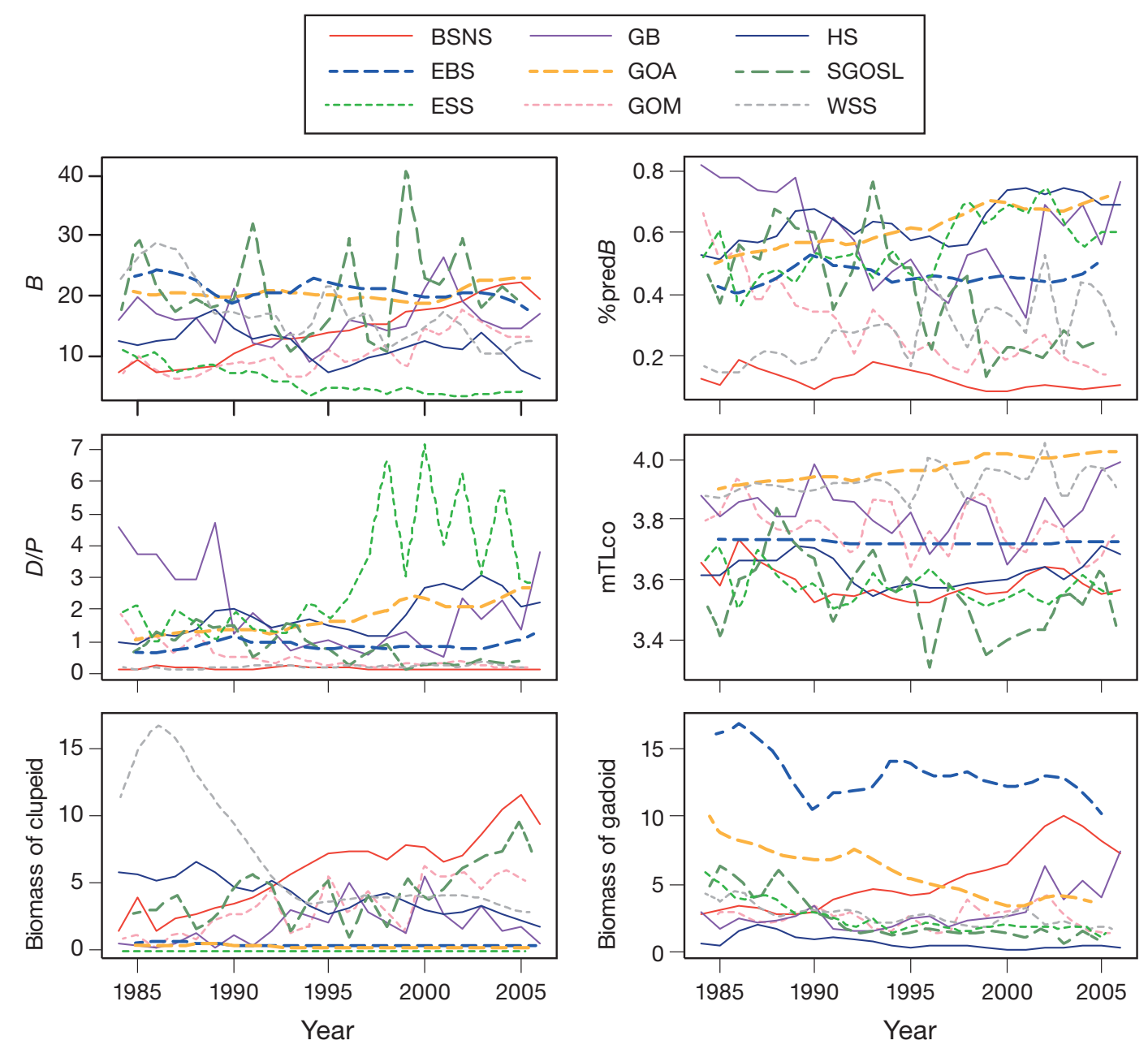

Fig. 1. Trajectories of 6 biomass-based response indicators - total biomass $\left(B, \mathrm{t} \mathrm{km}{ }^{-2}\right)$, percent of predatory biomass $(\%$ pred $B)$, demersal-to-pelagic biomass ratio $(D / P)$, mean trophic level of community (mTLco), biomass of clupeid ( $\mathrm{km}^{-2}$ ) and biomass of gadoid $\left(\mathrm{t} \mathrm{km}{ }^{-2}\right.$ ) — for the period from 1984 to 2006 in 9 ecosystems: the Barents Sea and Norwegian Sea (BSNS), eastern Bering Sea (EBS), Gulf of Alaska (GOA), Hecate Strait (HS), southern Gulf of St. Lawrence (sGOSL), eastern Scotian Shelf (ESS), western Scotian Shelf (WSS), Gulf of Maine (GOM) and Georges Bank (GB). Total biomass and biomass of gadoids for eastern Bering Sea were scaled down from original values by half for better presentation

the fishing-in-balance index for each ecosystem. The increasing trend of mean trophic level of the catch in Hecate Strait reflected a fishery targeting higher trophic level species and reduced Pacific herring Clupea pallasi abundance and catches. The dramatic reduction of mean trophic level of the catch in the eastern Scotian Shelf after the early 1990s indicated a shift in fishery strategies that targeted lower trophic level species.

\section{PLS regression diagnostics}

The first step in PLS regression is to determine the number of significant components, which indicates the complexity of the model and of the system. Ideally, much variation in the data should be explained with few components. Plots of RMSEPs as a function of the number of components showed that RMSEPs were generally minimized at 1 to 3 components for the majority of the indicators (plots not shown). The goodness of fit of PLS regression is given by the cumulative percent of variance explained $\left(R^{2}\right)$, and $R^{2}$ was generally significant for the predictor drivers as well as for the majority of response indicators in most of the ecosystems (Fig. 3). There were a few exceptions to this general result for certain ecosystem response indicators. Mean trophic level of community had consistently low $\mathrm{R}^{2}$ in all but 2 ecosystems, suggesting that alternative predictor drivers should 


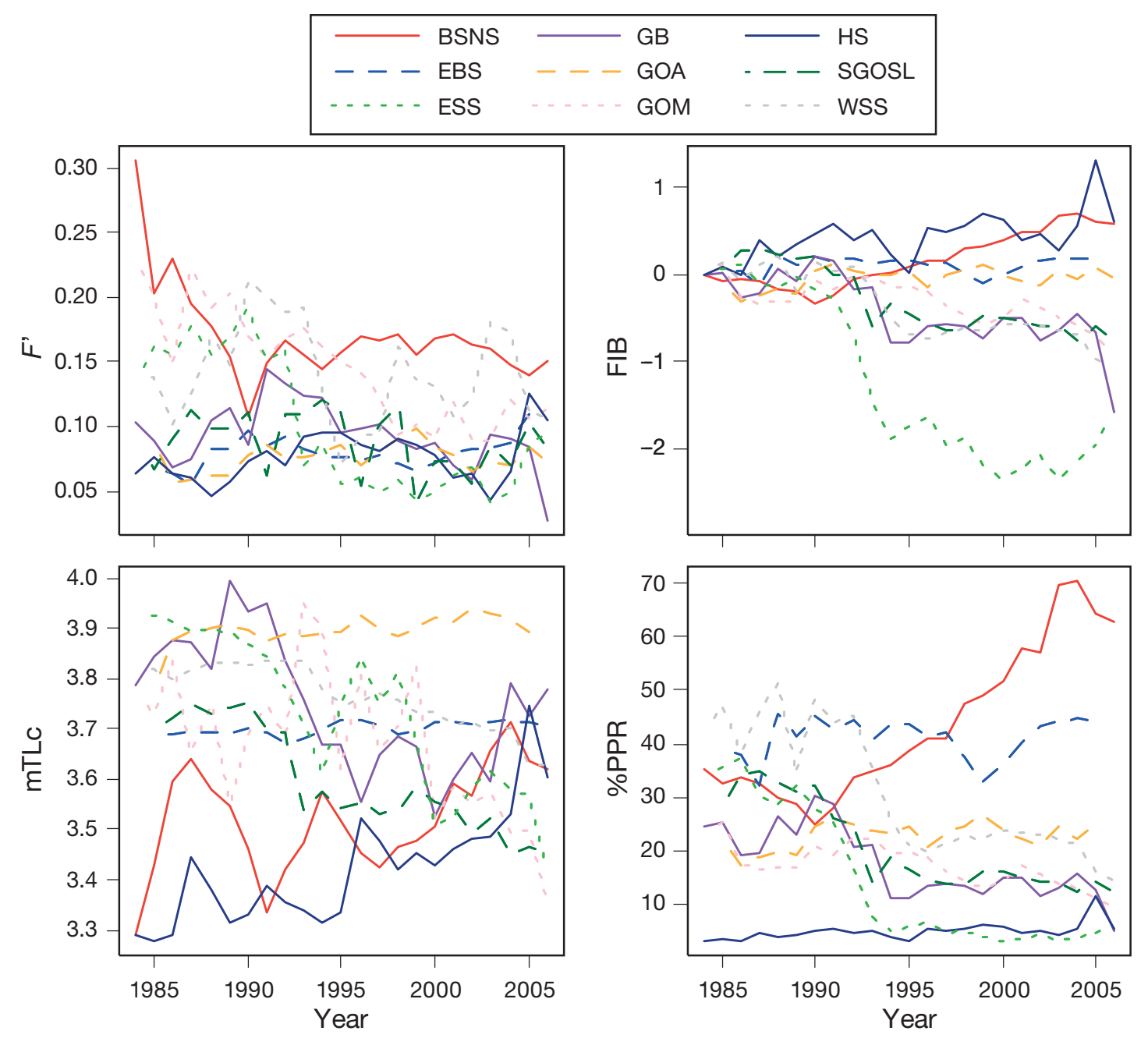

Fig. 2. Trajectories of 4 catch-based response indicators - exploitation rate $\left(F^{\prime}\right)$, fishing-in-balance (FIB), mean trophic level of catch (mTLc) and percent of primary production required to fisheries (\%PPR) - for the period from 1984 to 2006 in 9 ecosystems: the Barents Sea and Norwegian Sea (BSNS), eastern Bering Sea (EBS), Gulf of Alaska (GOA), Hecate Strait (HS), southern Gulf of St. Lawrence (sGOSL), eastern Scotian Shelf (ESS), western Scotian Shelf (WSS), Gulf of Maine (GOM) and Georges Bank (GB)

be identified and included in the model to address changes in ecosystem community structure. On the other hand, the percent of predatory biomass and demersal-to-pelagic biomass ratio indicators were well modeled with rather high $\mathrm{R}^{2}$ using 3 components in all but one ecosystem. The catch-based indicators, fishing-in-balance and percent primary production required to sustain fisheries, had high $\mathrm{R}^{2}$ at the first component for all but 2 ecosystems, indicating great explanatory capacity of the first component for these 2 indicators.

The residuals of the ecosystem response indicators were analyzed for autocorrelations, and results showed that the majority of response indicators did not have significant autocorrelation $(<0.3$, plots not shown) in all but 2 ecosystems. To address the autocorrelations in these 2 ecosystems, the eastern Bering Sea and the Gulf of Alaska, the predictor driver matrix was expanded to include variables with time lags of 1 and $3 \mathrm{yr}$, respectively. As a result, much smaller RMSEPs, higher $\mathrm{R}^{2}$, and nonsignificant autocorrelations in the indicator residuals were achieved for the eastern Bering Sea. However, the addition of lagged predictors did not render smaller RMSEPs or lower autocorrelations for the Gulf of Alaska. Instead, the addition of transformed catch (inverse) and environmental data (squared) resulted in much reduced RMSEPs and autocorrelations. For comparison purposes, we only focused on results based on the current (unlagged, normalized) predictor arrays. 
Fig. 3. Percent variance explained by the first 3 components (shown as a stacked histogram, with the first component shown as the darkest shaded bar and the third component as the lightest shaded bar) in overall predictor variables $(X)$ from the PLS analyses and each ecosystem response indicator: total biomass $(B)$, percent of predatory biomass $(\% \operatorname{pred} B)$, demersal-to-pelagic biomass ratio $(D / P)$, mean trophic level of community (mTLco), biomass of clupeids $\left(B_{\text {clupeid }}\right)$, biomass of gadoids $\left(B_{\text {gadoid }}\right)$, exploitation rate $\left(F^{\prime}\right)$, fishing in balance (FIB), mean trophic level of catch (mTLc) and percent of primary production required to sustain fisheries (\%PPR)

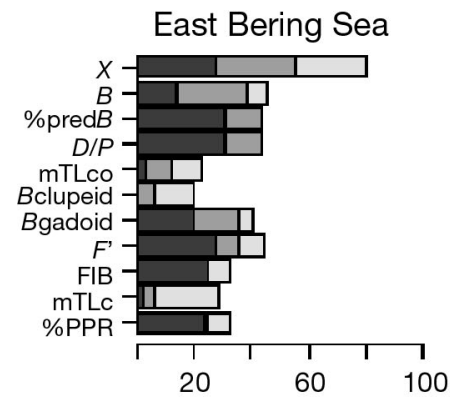

Barents \& Norwegian Seas
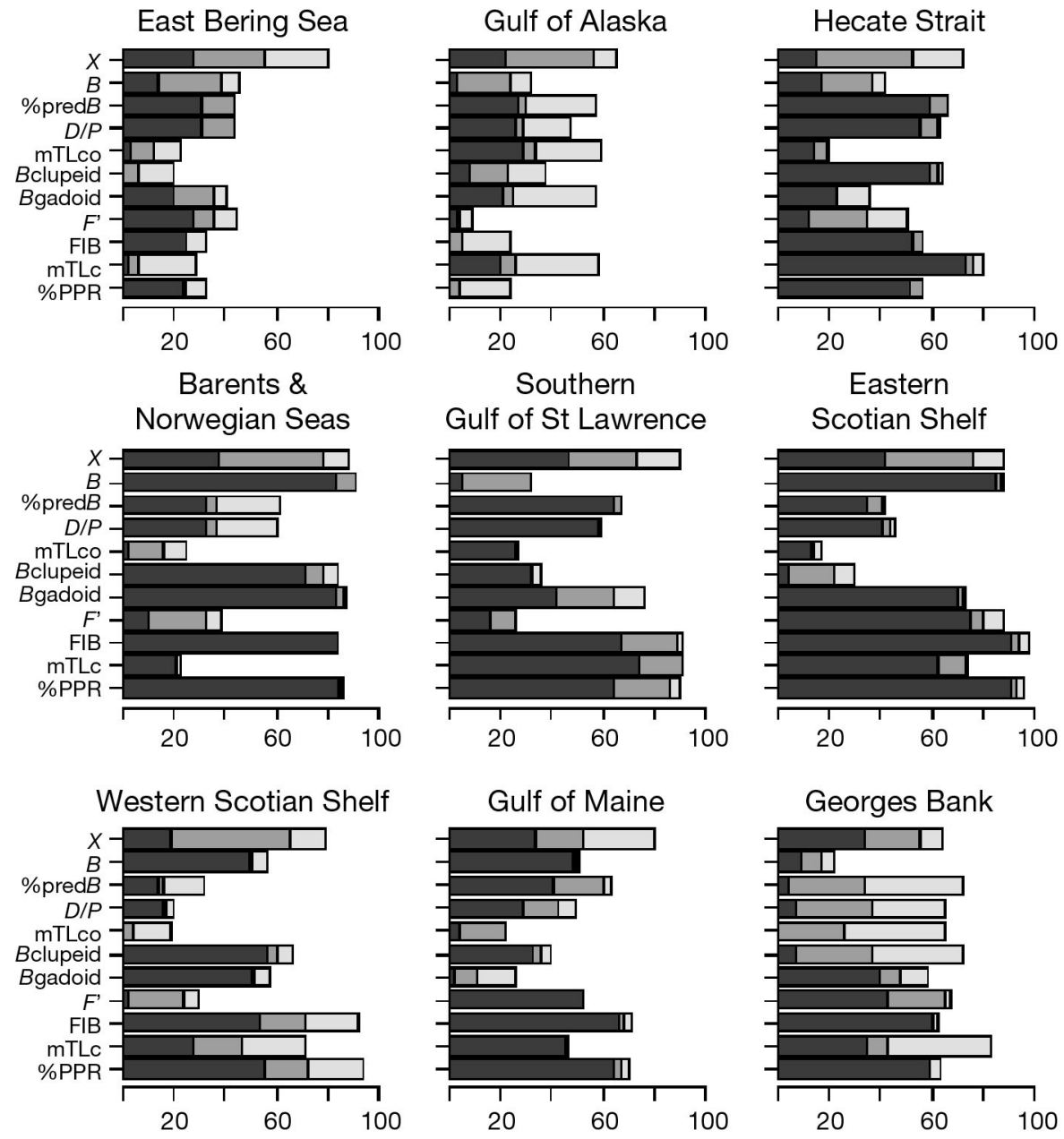

Eastern Scotian Shelf

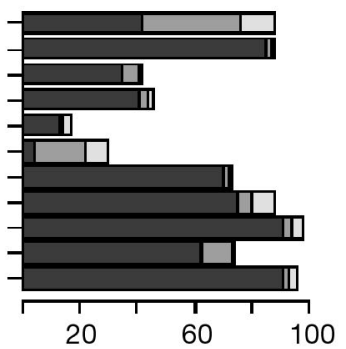

Gulf of Maine
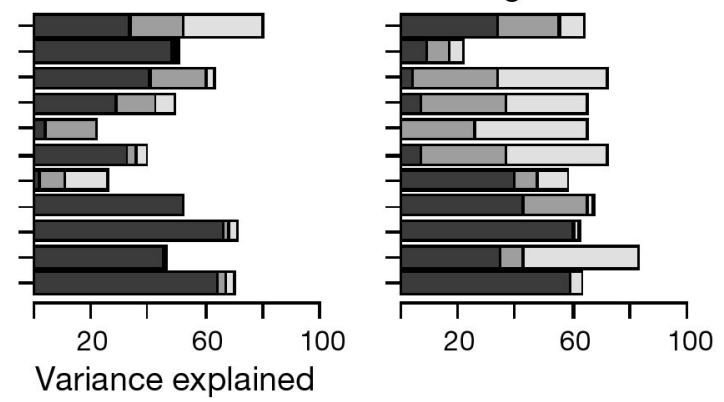

\section{Relative importance of the triad of drivers}

The coefficients obtained from PLS regression provide important information on the relative impact (either positive, negative, or none) of each predictor driver on each ecosystem response indicator (results shown in Table 2). The nonzero coefficients show that all of the ecosystems responded to both fisheries and environmental drivers, and all but one responded to available trophodynamic drivers as well. In general, fisheries drivers had the most widespread effect, producing the highest and the most numerous nonzero coefficients in relation to ecosystem response indicators across all systems. However, environmental and trophodynamic drivers were also important to key ecosystem response variables across systems, and some results for biomass-based indicators were surprising. It was particularly striking that in 4 out of the 9 ecosystems (eastern Bering Sea, Gulf of Alaska, southern Gulf of St. Lawrence and western
Scotian Shelf), total biomass was not related to any of the fisheries drivers, and in Georges Bank and the Gulf of Maine, total biomass was related only to the percent of piscivores and omnivores in the catch among fisheries drivers. In 3 out of the 9 ecosystems (Barents/Norwegian Seas, southern Gulf of St. Lawrence and Georges Bank), biomass of gadoids was affected by both fisheries and environmental drivers; while in other ecosystems, this indicator was influenced by fisheries and trophodynamic drivers (Gulf of Alaska, Hecate Strait, eastern Scotian Shelf and western Scotian Shelf), by environmental drivers (Gulf of Maine) or not at all (eastern Bering Sea).

Fisheries drivers had the most influence on the catch-based indicators across ecosystems, according to the magnitudes of PLS regression coefficients (Table 2). Of the fisheries drivers, 2 absolute catch indices and 1 catch proportion index appeared most influential across ecosystem response variables and ecosystems: catch of benthivores, piscivores and 
Table 2. Corrected coefficients of predictor drivers in relation to ecosystem response indicators including total biomass $(B)$, percent of predatory biomass $(\%$ pred $B)$, demersal-to-pelagic biomass ratio $(D / P)$, mean trophic level of community (mTLco), biomass of clupeids $\left(B_{\text {clupeid }}\right)$, biomass of gadoids $\left(B_{\text {gadoid }}\right)$, exploitation rate $\left(F^{\prime}\right)$, fishing-in-balance index (FIB), mean trophic level of catch (mTLc) and percent of primary production required to fisheries (\%PPR) for the 9 ecosystems. The predictor drivers for fisheries include percentage and weight of total catch for 3 combinations of different feeding guilds: planktivores and zoopivores (\% PZ, PZ), piscivores and omnivores (\% $\mathrm{PiO}, \mathrm{PiO})$ and benthivores, piscivores and omnivores $(\% \mathrm{BPiO}, \mathrm{BPiO})$; for trophodynamic and environmental drivers, refer to Table 1 for full names. Nonzero values indicate significance

\begin{tabular}{|c|c|c|c|c|c|c|c|c|c|c|c|c|c|c|}
\hline \multirow{2}{*}{$\frac{\text { System }}{\text { Eastern Be }}$} & \multicolumn{6}{|c|}{ Fisheries driver } & \multicolumn{2}{|c|}{ | Trophodynamic driver } & \multicolumn{6}{|c|}{ Environmental driver } \\
\hline & \multicolumn{6}{|c|}{ ring Sea } & \multirow{2}{*}{\multicolumn{2}{|c|}{ Bcope }} & \multirow[b]{2}{*}{ sSST } & \multirow[b]{2}{*}{ ice } & \multirow[b]{2}{*}{ ONI } & \multirow[b]{2}{*}{ NPI } & \multirow[b]{2}{*}{ ALPI } & \multirow[b]{2}{*}{$\mathrm{PDO}$} \\
\hline Indicator & $\% \mathrm{PZ}$ & $\% \mathrm{PiO}$ & $\% \mathrm{BPiO}$ & $\mathrm{PZ}$ & $\mathrm{PiO}$ & $\mathrm{BPiO}$ & & & & & & & & \\
\hline$B$ & 0 & 0 & 0 & 0 & 0 & 0 & 0 & & 0 & 0 & 0 & 0 & 0 & 0 \\
\hline$\%$ pred $B$ & 0 & 0.56 & 0 & 0 & 0 & 0 & 0 & & 0 & 0 & 0 & 0 & 0 & 0 \\
\hline$D / P$ & 0 & 0.25 & 0 & 0 & 0 & 0 & 0 & & 0.13 & 0 & 0 & 0 & -0.19 & 0 \\
\hline mTLco & 0 & 0 & 0 & 0 & 0 & 0 & 0.4 & & 0 & 0 & 0 & 0 & 0 & 0 \\
\hline$B_{\text {clupeid }}$ & -0.26 & 0 & 0 & 0 & 0.26 & 0 & 0 & & 0 & 0 & 0 & 0 & 0 & 0 \\
\hline$B_{\text {gadoid }}$ & 0 & 0 & 0 & 0 & 0 & 0 & 0 & & 0 & 0 & 0 & 0 & 0 & 0 \\
\hline$F^{\prime}$ & 0.18 & 0.29 & 0 & 0 & -0.18 & 0 & 0 & & 0.16 & 0 & 0 & 0 & 0 & 0 \\
\hline FIB & 0 & 0.84 & 0 & 0 & 0 & 0 & 0 & & 0 & 0 & 0 & 0 & 0 & 0 \\
\hline mTLc & 0.18 & 0 & 0 & 0 & -0.18 & -0.18 & 0 & & 0.14 & 0 & 0 & 0 & 0 & 0 \\
\hline$\% \mathrm{PPR}$ & 0 & 0.93 & 0 & 0.26 & 0 & 0.37 & 0 & & 0 & 0 & 0 & 0 & 0 & 0 \\
\hline \multicolumn{15}{|c|}{ Gulf of Alaska } \\
\hline Indicator & \%PZ & $\% \mathrm{PiO}$ & $\% \mathrm{BPiO}$ & $\mathrm{PZ}$ & $\mathrm{PiO}$ & $\mathrm{BPiO}$ & & & sSST & discharge & ONI & NPI & ALPI & PDO \\
\hline$B$ & 0 & 0 & 0 & 0 & 0 & 0 & & & 0.63 & 0 & 0 & 0 & 0 & 0 \\
\hline$\%$ pred $B$ & -0.13 & 0 & 0.14 & 0.13 & 0.13 & 0.12 & & & 0 & 0 & 0 & 0 & 0 & 0 \\
\hline$D / P$ & -0.11 & 0 & 0.12 & 0.12 & 0.11 & 0.11 & & & 0 & 0 & 0 & 0 & 0 & 0 \\
\hline mTLco & -0.13 & 0 & 0.14 & 0.13 & 0.13 & 0.12 & & & 0 & 0 & 0 & 0 & 0 & 0 \\
\hline$B_{\text {clupeid }}$ & 0.11 & 0 & -0.12 & -0.12 & -0.11 & -0.12 & & & 0 & 0 & 0 & 0 & 0 & 0 \\
\hline$B_{\text {gadoid }}$ & 0.19 & 0 & -0.2 & -0.19 & -0.19 & 0 & & & 0 & 0 & 0 & 0 & 0 & 0 \\
\hline$F^{\prime}$ & 0 & 0.54 & 0 & 0 & 0 & 0 & & & 0 & 0 & 0 & 0 & 0 & 0 \\
\hline FIB & 0 & 0 & 0 & 0.31 & 0 & 0.33 & & & 0 & 0 & 0 & 0 & 0 & 0 \\
\hline mTLc & -0.17 & -0.17 & 0.18 & 0.14 & 0.17 & 0.13 & & & 0 & 0 & 0 & 0 & 0 & 0 \\
\hline$\% \mathrm{PPR}$ & 0 & 0.81 & 0 & 0.46 & 0 & 0.5 & & & 0 & 0 & 0 & 0 & 0 & 0 \\
\hline \multicolumn{15}{|c|}{ Hecate Strait } \\
\hline Indicator & $\% \mathrm{PZ}$ & $\% \mathrm{PiO}$ & $\% \mathrm{BPiO}$ & $\mathrm{PZ}$ & $\mathrm{PiO}$ & $\mathrm{BPiO}$ & & Bafl & wSST & wSSH & ONI & NPI & ALPI & $\mathrm{PDO}$ \\
\hline$B$ & 0 & 0.64 & -0.37 & 0 & 0 & 0 & & 0 & 0.54 & 0 & 0 & 0 & 0 & 0 \\
\hline$\%$ pred $B$ & -0.1 & 0 & 0.11 & 0.1 & 0.1 & 0.09 & & 0.14 & 0 & 0 & 0 & 0 & 0 & 0.06 \\
\hline$D / P$ & 0 & 0 & 0 & 0 & 0 & 0 & & 0.76 & 0 & 0 & 0 & 0 & 0 & 0 \\
\hline mTLco & 0 & 0 & 0 & 0 & 0 & 0 & & 0.55 & 0 & 0 & 0 & 0 & 0 & 0 \\
\hline$B_{\text {clupeid }}$ & 0.12 & 0.11 & -0.14 & -0.12 & -0.12 & -0.11 & & -0.11 & 0 & 0 & 0 & 0 & 0 & 0 \\
\hline$B_{\text {gadoid }}$ & 0.08 & 0.07 & -0.1 & -0.09 & -0.08 & -0.07 & & -0.08 & 0 & 0 & 0 & 0 & 0 & 0 \\
\hline$F^{\prime}$ & 0 & 0 & 0 & 0.61 & 0 & 0 & & 0 & 0 & 0 & 0 & 0 & 0 & 0 \\
\hline FIB & -0.13 & 0 & 0.13 & 0.16 & 0.13 & 0.17 & & 0.11 & 0 & 0.05 & 0 & 0 & 0 & 0 \\
\hline mTLc & -0.16 & -0.13 & 0.16 & 0.15 & 0.16 & 0.15 & & 0.12 & 0 & 0 & 0 & 0 & 0 & 0 \\
\hline$\% \mathrm{PPR}$ & 0 & 0.44 & 0.18 & 0.52 & 0 & 0.51 & & 0 & 0 & 0 & 0 & 0 & 0 & 0 \\
\hline \multicolumn{15}{|c|}{ Barents/Norwegian Seas } \\
\hline Indicator & $\% \mathrm{PZ}$ & $\% \mathrm{PiO}$ & $\% \mathrm{BPiO}$ & $\mathrm{PZ}$ & $\mathrm{PiO}$ & $\mathrm{BPiO}$ & Bzoo & Bseal & BS_SST & I NS_SST & ice & NS_NA & & \\
\hline$B$ & 0.13 & 0.14 & -0.1 & 0 & 0 & 0.18 & 0.09 & 0.19 & 0.14 & 0.26 & 0 & 0 & & \\
\hline$\%$ pred $B$ & 0 & 0 & 0 & 0 & 0.7 & 0 & 0 & 0 & 0 & 0 & 0 & 0 & & \\
\hline$D / P$ & 0 & 0 & 0 & 0 & 0.69 & 0 & 0 & 0 & 0 & 0 & 0 & 0 & & \\
\hline mTLco & 0 & 0 & 0 & 0 & 0 & 0 & -0.4 & 0 & -0.36 & 0 & 0 & 0 & & \\
\hline$B_{\text {clupeid }}$ & 0 & 0.15 & 0 & 0 & 0 & 0.34 & 0.21 & 0 & 0 & 0 & 0 & 0 & & \\
\hline$B_{\text {gadoid }}$ & 0.26 & 0.22 & 0 & 0 & 0 & 0.18 & 0 & 0 & 0 & 0.49 & 0 & 0 & & \\
\hline$F^{\prime}$ & 0 & 0 & 0 & 0 & 0 & 0 & -0.14 & -0.12 & -0.17 & -0.19 & 0 & 0 & & \\
\hline FIB & 0.18 & 0.21 & -0.13 & 0.15 & 0 & 0 & 0 & 0.17 & 0 & 0.18 & 0.13 & 0 & & \\
\hline mTLc & 0 & 0 & 0 & 0 & 0 & 0 & 0 & 0 & 0 & 0.18 & 0 & 0 & & \\
\hline$\%$ PPR & 0 & 0.7 & 0 & 0 & 0 & 0.21 & 0 & -0.25 & 0 & 0.46 & 0 & 0 & & \\
\hline
\end{tabular}


Table 2 (continued)

\begin{tabular}{|c|c|c|c|c|c|c|c|c|c|c|c|c|c|c|c|}
\hline System & \multicolumn{6}{|c|}{ Fisheries driver } & \multicolumn{3}{|c|}{ Trophodynamic driver } & \multicolumn{6}{|c|}{ Environmental driver } \\
\hline \multicolumn{16}{|c|}{ Southern Gulf of St. Lawrence } \\
\hline Indicator & $\% \mathrm{PZ}$ & $\% \mathrm{PiO}$ & $\% \mathrm{BPiO}$ & $\mathrm{PZ}$ & $\mathrm{PiO}$ & $\mathrm{BPiO}$ & Bszoo & Blzoo & Bseal & SST & $90 \mathrm{mT}$ & & & & 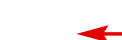 \\
\hline$B$ & 0 & 0 & 0 & 0 & 0 & 0 & 0 & 0.24 & 0 & 0 & 0.2 & & & & \\
\hline$\%$ pred $B$ & 0 & 0 & 0 & 0.23 & 0 & 0 & 0 & 0 & -0.31 & -0.32 & 0 & & & & \\
\hline$D / P$ & 0 & 0 & 0.13 & 0.14 & 0 & 0.12 & 0 & -0.11 & -0.17 & -0.17 & -0.1 & & & & \\
\hline mTLco & 0 & 0 & 0 & 0 & 0 & 0 & 0 & 0 & 0 & -0.49 & 0 & & & & \\
\hline$B_{\text {clupeid }}$ & 0 & 0 & 0 & 0 & 0 & 0.58 & 0 & 0 & 1.09 & 0 & 0 & & & & \\
\hline$B_{\text {gadoic }}$ & 0 & 0 & 0 & 0.2 & 0 & 0.22 & 0 & 0 & -0.28 & 0 & 0.32 & & & & \\
\hline$F^{\prime}$ & 0 & 0 & 0 & 0 & 0 & 0 & 0 & -0.18 & 0 & -0.14 & 0 & & & & \\
\hline FIB & -0.05 & 0.31 & 0.21 & 0.25 & 0.05 & 0.21 & 0 & 0 & -0.25 & 0 & 0 & & & & \\
\hline mTLc & -0.12 & 0 & 0.17 & 0.17 & 0.12 & 0.16 & 0.08 & 0 & -0.17 & -0.11 & 0 & & & & \\
\hline$\%$ PPR & -0.06 & 0.38 & 0.24 & 0.31 & 0.06 & 0.27 & 0 & 0 & 0 & 0 & 0 & & & & \\
\hline \multicolumn{16}{|c|}{ Eastern Scotian Shelf } \\
\hline Indicator & $\% \mathrm{PZ}$ & $\% \mathrm{PiO}$ & $\% \mathrm{BPiO}$ & $\mathrm{PZ}$ & $\mathrm{PiO}$ & $\mathrm{BPiO}$ & & & Bseal & SST & sBT & $50 \mathrm{mT}$ & $100 \mathrm{~m}$ & $\Gamma$ strat & \\
\hline$B$ & 0 & 0.24 & 0 & 0.24 & 0 & 0.32 & & & 0 & 0 & 0 & 0 & 0 & 0 & \\
\hline$\% \operatorname{pred} B$ & 0 & -0.13 & -0.10 & -0.11 & 0 & -0.10 & & & 0.14 & 0.09 & 0.00 & 0 & 0 & 0 & \\
\hline$D / P$ & 0 & -0.34 & 0 & 0 & 0 & 0 & & & 0.36 & 0 & 0 & 0 & 0 & 0 & \\
\hline mTLco & 0 & 0 & 0 & 0 & 0 & 0 & & & 0 & 0 & 0 & 0 & 0 & 0 & \\
\hline$B_{\text {clupeid }}$ & 0 & 0 & 0 & 0 & 0 & 0 & & & 0 & 0 & 0 & 0 & 0.15 & -0.11 & \\
\hline$B_{\text {gadoid }}$ & 0 & 0 & 0 & 0.29 & 0 & 0.27 & & & 0 & 0 & 0 & 0 & 0 & 0 & \\
\hline$F^{\prime}$ & 0 & 0.18 & 0.18 & 0.18 & 0 & 0.18 & & & -0.16 & 0 & 0 & 0 & 0 & -0.08 & \\
\hline FIB & 0 & 0.21 & 0.20 & 0.21 & 0 & 0.20 & & & -0.19 & 0 & 0 & 0 & 0 & 0 & \\
\hline mTLc & 0 & 0.18 & 0.17 & 0.17 & 0 & 0.15 & & & -0.19 & 0 & 0 & 0 & 0 & 0 & \\
\hline$\% \mathrm{PPR}$ & 0 & 0.37 & 0 & 0.27 & 0 & 0.29 & & & 0 & 0 & 0 & 0 & 0 & 0 & \\
\hline \multicolumn{16}{|c|}{ Western Scotian Shelf } \\
\hline Indicator & $\% \mathrm{PZ}$ & $\% \mathrm{PiO}$ & $\% \mathrm{BPiO}$ & $\mathrm{PZ}$ & $\mathrm{PiO}$ & $\mathrm{BPiO}$ & & & & SST & sBT & $50 \mathrm{mT}$ & $100 \mathrm{~m}$ & $\Gamma$ strat & BoFstrat \\
\hline$B$ & 0 & 0 & 0 & 0 & 0 & 0 & & & & 0 & 0 & 0 & 0 & 0 & 0 \\
\hline$\% \operatorname{pred} B$ & -0.1 & -0.13 & 0 & -0.13 & 0.1 & -0.13 & & & & 0 & 0 & 0 & 0 & 0 & 0 \\
\hline$D / P$ & 0 & -0.39 & 0 & 0 & 0 & 0 & & & & 0 & 0 & 0 & 0 & 0 & 0 \\
\hline mTLco & -0.06 & -0.08 & 0 & -0.07 & 0.06 & -0.07 & & & & 0 & 0 & 0 & 0 & 0 & 0 \\
\hline$B_{\text {clupeid }}$ & 0.14 & 0.19 & 0 & 0.17 & -0.15 & 0.18 & & & & 0 & 0 & 0 & 0 & -0.13 & 0 \\
\hline$B_{\text {gadoid }}$ & 0 & 0 & 0 & 0.37 & 0 & 0.41 & & & & 0 & 0 & 0 & 0 & 0 & 0 \\
\hline$F^{\prime}$ & 0.14 & 0.14 & 0 & 0.11 & -0.14 & 0.1 & & & & 0 & 0 & 0 & 0 & 0 & 0 \\
\hline FIB & 0 & 0.36 & 0 & 0.34 & 0 & 0.32 & & & & 0 & 0 & 0 & 0 & 0 & 0 \\
\hline mTLc & 0.2 & 0.19 & 0.13 & 0.21 & -0.19 & 0.16 & & & & 0 & 0 & 0 & 0 & 0 & 0 \\
\hline$\%$ PPR & 0.16 & 0.25 & 0 & 0.24 & -0.16 & 0.25 & & & & 0 & 0 & 0 & 0 & -0.07 & 0 \\
\hline \multicolumn{16}{|c|}{ Gulf of Maine } \\
\hline Indicator & $\% \mathrm{PZ}$ & $\% \mathrm{PiO}$ & $\% \mathrm{BPiO}$ & PZ & $\mathrm{PiO}$ & $\mathrm{BPiO}$ & Bzoo & & & SST & NAO & $\mathrm{AMO}$ & & & \\
\hline$B$ & 0 & 0.18 & 0 & 0 & 0 & 0 & 0 & & & 0 & 0 & 0 & & & \\
\hline$\% \operatorname{pred} B$ & 0 & 0 & 0 & 0 & 0 & 0.43 & 0 & & & 0 & 0 & -0.42 & & & \\
\hline$D / P$ & -0.13 & 0 & 0.09 & 0.1 & 0.13 & 0.15 & 0 & & & 0 & 0 & -0.13 & & & \\
\hline mTLco & -0.15 & -0.17 & 0.12 & 0 & 0.15 & 0 & 0 & & & 0 & 0 & 0 & & & \\
\hline$B_{\text {clupeid }}$ & 0.18 & 0.16 & -0.16 & 0 & -0.18 & 0 & 0 & & & 0 & 0 & 0.15 & & & \\
\hline $\begin{array}{l}\text { Lclupeld } \\
B_{\text {gadoid }}\end{array}$ & 0 & 0 & 0 & 0 & 0 & 0 & 0 & & & 0.39 & 0 & 0 & & & \\
\hline$F^{\prime}$ & 0 & 0 & 0 & 0.24 & 0 & 0.24 & 0 & & & 0 & 0 & -0.26 & & & \\
\hline FIB & -0.12 & 0 & 0.14 & 0.18 & 0.12 & 0.17 & 0 & & & 0 & 0 & -0.17 & & & \\
\hline mTLc & -0.17 & -0.16 & 0.17 & 0.1 & 0.17 & 0.1 & 0 & & & 0 & 0 & -0.13 & & & \\
\hline$\% \mathrm{PPR}$ & 0 & 0 & 0 & 0.33 & 0 & 0.31 & 0 & & & 0 & 0 & -0.31 & & & \\
\hline \multicolumn{16}{|c|}{ Georges Bank } \\
\hline Indicator & $\% \mathrm{PZ}$ & $\% \mathrm{PiO}$ & $\% \mathrm{BPiO}$ & PZ & $\mathrm{PiO}$ & $\mathrm{BPiO}$ & Bzoo & & & SST & NAO & $\mathrm{AMO}$ & & & \\
\hline$B$ & 0 & 0.88 & 0 & 0 & 0 & 0 & 0 & & & 0.58 & -0.31 & 0 & & & \\
\hline$\%$ pred $B$ & -0.19 & -0.18 & 0.14 & 0.1 & 0.19 & 0.11 & 0 & & & 0 & 0 & 0 & & & \\
\hline$D / P$ & -0.41 & 0 & 0 & 0 & 0.41 & 0 & 0 & & & 0 & 0 & 0 & & & \\
\hline mTLco & -0.18 & -0.21 & 0 & 0 & 0.18 & 0 & -0.06 & & & 0 & 0 & 0 & & & \\
\hline$B_{\text {clupeid }}$ & 0.24 & 0.24 & -0.21 & 0 & -0.24 & 0 & 0 & & & 0 & 0 & 0 & & & \\
\hline$B_{\text {gadoid }}$ & -0.19 & -0.28 & -0.11 & -0.2 & 0.19 & 0 & 0 & & & 0 & 0 & 0.3 & & & \\
\hline$F^{\prime}$ & 0 & 0 & 0 & 0.18 & 0 & 0 & 0 & & & -0.2 & 0.19 & -0.22 & & & \\
\hline FIB & 0 & 0 & 0.25 & 0.33 & 0 & 0.34 & 0 & & & 0 & 0 & 0 & & & \\
\hline mTLc & 0 & 0 & 0.9 & 0 & 0 & 0 & 0 & & & 0 & 0 & 0 & & & \\
\hline$\%$ PPR & 0 & 0.19 & 0 & 0.64 & 0 & 0.41 & 0 & & & 0 & 0 & 0 & & & \\
\hline
\end{tabular}

Column headings corrected after publication 
omnivores; catch of planktivores and zoopivores; and the proportion of piscivores and omnivores in the catch. The percent primary production required to sustain fisheries was always affected by at least 2 of these fisheries drivers, and it was most closely related to the percent of piscivores and omnivores in the catch for 6 out of the 9 ecosystems (Barents/Norwegian Seas, eastern Bering Sea, Gulf of Alaska, eastern Scotian Shelf, western Scotian Shelf and southern Gulf of St. Lawrence). The same set of drivers was also most influential on the fishing-in-balance index, although individual driver effects were mixed. The percent of piscivores and omnivores in the catch influenced this index most in the Barents/Norwegian Seas, eastern Bering Sea, western Scotian Shelf and southern Gulf of St. Lawrence, but the same driver had no influence on the fisheries-in-balance index for another 4 ecosystems (Hecate Strait, Gulf of Alaska, Georges Bank and Gulf of Maine) where the absolute catch of benthivores, piscivores and omnivores was most relevant. In 4 systems (Gulf of Alaska, Hecate Strait, western Scotian Shelf and Gulf of Maine), mean trophic level of catch was affected by all of the fisheries drivers, whereas in Barents/Norwegian Seas, there were no apparent fisheries effects on this index.

Environmental drivers, particularly temperaturerelated independent variables (e.g. SST) were also important across all ecosystems, with high coefficients in relation to biomass-based ecosystem response indicators. In particular, total biomass (i.e. Barents/Norwegian Seas, Gulf of Alaska, Hecate Strait, southern Gulf of St. Lawrence and Georges Bank), biomass of gadoids (i.e. Barents/Norwegian Seas, southern Gulf of St. Lawrence, Georges Bank and Gulf of Maine), biomass of clupeids (eastern Scotian Shelf, western Scotian Shelf and Gulf of Maine) and percent of predatory biomass (eastern Scotian Shelf, southern Gulf of St. Lawrence and Gulf of Maine) appeared to be at least partially environmentally driven.

Although trophodynamic driver time series were unavailable in several ecosystems, and less numerous across all ecosystems than fisheries or environmental drivers, we note that their coefficients are of similar magnitude to the other drivers in all of the cases where they could be included. Trophodynamic drivers had the highest coefficients in relation to mean trophic level in the community (Barents/ Norwegian Seas, eastern Bering Sea and Georges Bank), demersal-to-pelagic biomass ratio (Hecate Strait and eastern Scotian Shelf) and biomass of clupeids (southern Gulf of St. Lawrence).

\section{DISCUSSION}

This is the first application of PLS regression for modeling the relationships between ecosystem indicators and the triad of drivers: fisheries, trophodynamic and environmental. The results of our PLS regression modeling have provided important insights into the relative importance of the triad of drivers affecting the dynamics of ecosystem indicators, outlined here and detailed below. First, the full triad of drivers needs to be considered to understand fishery production - across 9 diverse northern hemisphere ecosystems, none were influenced by only a single driver type. We found that fishing is an important driver across all ecosystems, that environmental drivers are often more important to ecosystem biomass indicators than fishing drivers and that trophodynamic drivers can be very influential in individual ecosystems, despite a general lack of time series data for this type of driver. Within individual ecosystems, the relative importance of the triad of drivers is context dependent. This work clearly illustrates the value of long-term ecological time series combined with the comparative approach in ecological investigations.

\section{Empirical evidence that the triad of drivers influence fisheries production}

It is clear from our results that fisheries, trophodynamic and environmental drivers shape critical aspects of fishery production. Across 9 ecosystems spanning the north Pacific and Atlantic ocean basins from subarctic to temperate regions, all showed evidence that multiple classes of drivers influence ecosystem responses. While this result may seem intuitive from an ecological standpoint, fisheries production investigations have often focused on a single driver type, most often either fishing or the environment. This dichotomy was illustrated most famously for single-species production in the ThompsonBurkenroad debate of the 1950s, where Thompson maintained that changes in Pacific halibut Hippoglossus stenolepis populations were directly attributable to changes in fishing, while Burkenroad argued that 'natural causes' drove population dynamics (Beverton \& Holt 1957, Skud 1975). Although most current arguments regarding drivers of production are not this extreme, it is still common to have environmental and fisheries effects on population and ecosystem productivity studied separately (e.g. Link 2010: most standard stock assessments ignore environment/ 
trophodynamics while biology/ecology investigations ignore fishing). Based on our results and those of many others (e.g. Blanchard et al. 2010, Shannon et al. 2010, Shin et al. 2010a,b, Link et al. 2010b), these lines of investigation should be integrated.

The importance of fishing as a driver of exploited marine ecosystem dynamics is not surprising, but our results show fishing within the context of a full suite of drivers. While fisheries drivers had the most consistent influence on the catch-based ecosystem indicators across all ecosystems, with clear influence on biomass-based indicators in many systems, the coefficients were often of a similar magnitude to those estimated for environmental or trophodynamic drivers on the same indicators, suggesting a similar level of influence. However, the influence of fishing was not always observed at the full-ecosystem level: in 4 out of the 9 ecosystems, total biomass was not related to any of the fisheries drivers (in 2 of those systems, it was unrelated to any of the drivers). While some of these results may arise from differences among ecosystems in the availability of time series for constructing ecosystem response variables, the general implication that fisheries are important but not exclusive drivers of production remains clear.

Despite the clear importance of fisheries as drivers of ecosystem productivity, our results demonstrate that environmental drivers may be even more influential on ecosystem attributes related to biomass. While some environmental drivers showed little influence on the ecosystem response indicators (particularly for the ONI and NPI indices in the Pacific ecosystems), high (>0.3) coefficients showed the strong influence of SST on one or more biomass-based indicators for 6 of the 9 systems. This result suggests that climate-driven changes in SST may have important ecosystem-level effects, reinforcing the need to monitor environmental as well as fishery drivers in assessing marine ecosystems.

Trophodynamic drivers were clearly important in affecting ecosystems, exhibiting some of the highest influence on ecosystem response indicators in several systems. Apex predator time series showed particularly high influence over both biomass and catchbased ecosystem indicators in 3 of the 4 ecosystems where they were included. Although zooplankton time series were rare, when available, they showed an influence on ecosystem response similar to that of fisheries. These results suggest that further work to assemble time series representing major bottom-up and top-down trophodynamic drivers in a wider range of ecosystems will result in better understanding of ecosystem productivity. Further, improving the availability of trophodynamic drivers, including biomass of mesozooplankton and top-level predators, may improve our ability to explain changes in the mean trophic level of the community, an indicator that is regarded as important (Libralato et al. 2008, Shin et al. 2010a), but was largely unexplained in our analysis.

\section{Context dependence of driver importance}

While there were similarities across ecosystems with respect to the general importance of all 3 driver types, it was clear from our results that contiguous ecosystems may not always respond synchronously to common drivers, regardless of driver type. This suggests that the relative importance of the triad of drivers will be context dependent, with local histories modulating broad-scale, basin-level drivers, and with key trophodynamic and environmental drivers likely to be system specific. Some basin-scale patterns were apparent from our results, probably owing to some common ecosystem context across the ecosystems, with potential implications for fisheries management. For example, the negative and declining trends in the fishing-in-balance indices of the eastern Atlantic ecosystems in the 1990s provided a warning that the functioning of these ecosystems had been impaired by the impacts of fishing. The reduction of mean trophic level of catch in these 6 ecosystems highlighted an additional concern that the fishing patterns had 'fished down the foodweb', which can indicate the loss of higher trophic level species, with consequent impacts on the ecosystem vulnerability (Pauly \& Watson 2005, Bundy et al. 2009). Fortunately, the similarly decreasing trend in percent of primary production required to sustain fisheries indicated that more cautious fisheries management strategies have operated in the last decade.

Our results for the remaining ecosystems further demonstrate the context dependence of driver importance. In the Pacific Ocean, ecosystems either showed balanced (i.e. eastern Bering Sea and Gulf of Alaska) or a positive and slightly increasing trend (Hecate Strait) in the fishing-in-balance indices. The increasing trend of mean trophic level of the catch in Hecate Strait indicates that higher trophic level species are being targeted, since catches of Pacific herring declined and no longer comprise the majority of the commercially caught fish, resulting in exploitation that is more balanced across trophic levels. In the Barents/Norwegian Seas, the fishing-in-balance index started to increase after 1990 indicating fishery 
expansion in the last 2 decades; Atlantic herring Clupea harengus in the Norwegian Sea had recovered and the fishery increased to take advantage of this increased productivity (Holst et al. 2002). Also of note is that our analysis suggests the presence of lags in the response of ecosystems to changes in the intensity of any of the drivers. For example fishing activity has been reduced on the eastern Scotian Shelf, yet dramatic reductions of mean trophic level of the catch along with other indicators such as total biomass and percent primary production required in the eastern Scotian Shelf were still observed (Bundy et al. 2005).

Overall, comparisons of 10 indicators across 9 northern hemisphere ecosystems indicated that different ecosystem indicators responded to the triad of drivers differently, and it may be necessary to further include more ecosystem-specific indicators in order to better understand the different impacts from multiple drivers (see below). Each of the triad of drivers was important for all ecosystems; however, the relative importance of each driver and the indicators they most affected varied among ecosystems, reinforcing the finding that an examination of a suite of indicators and drivers is required. Further analyses like PLS regression modeling and exploration is warranted for each ecosystem in order to identify additional driver variables and improve model predictive ability.

\section{Implications for ecosystem-based management}

Marine ecosystems are inherently complex, influenced by a triad of fisheries, trophodynamic and environmental drivers, and such complexity requires that the management of marine fisheries adopt a more holistic approach. Correspondingly, ecosystembased fisheries management (EBFM) has been advocated to account for both fishing and environmental processes, in conjunction with species interactions when formulating fisheries management advice (e.g. Pikitch et al. 2004, Sissenwine \& Murawski 2004, Link 2010). To support the implementation of EBFM, it is important to develop and monitor indicators to assess ecosystem status and the effectiveness of management strategies (Cury \& Christensen 2005, Shin et al. 2010b). Further, a standardized set of ecosystem indicators that can be applied across ecosystems may be desirable as a basis for EBFM (e.g. Shin et al. 2010b). Travers et al. (2006) showed that indicators did not always vary as predicted from first principles because of indirect effects of fishing on the different components of the ecosystem. Consequently, the fishing configuration (species targeted, fishing intensity) and the type of community should be incorporated into the development and evaluation of ecosystem indicators.

Our results suggest that EBFM should focus on considering the effects of fishing on ecosystem indicators as a standard approach across ecosystems, while component-specific ecosystem indicators should be tailored to individual ecosystems. We explored ecologically oriented, component-specific indicators, such as biomass of gadoids, biomass of clupeids and the demersal-to-pelagic biomass ratio in addition to the commonly used integrative indicators such as total biomass, mean trophic level in the catch, mean trophic level in the community, fishing in balance and percent of primary production required to sustain fisheries. Likewise, we examined component-specific fisheries drivers including the catch and catch percentages of certain aggregate groups (e.g. catch and catch percentage of planktivores and zoopivores). We found that the component-specific biomass indicators were sensitive to the suite of drivers in some ecosystems, but were not universally sensitive indicators across all ecosystems. However, component-specific fisheries drivers did produce significant responses across ecosystems and ecosystem indicators.

Although our main focus was a comparison across ecosystems, EBFM is implemented within particular ecosystems such that further augmentation of the standardized indicator approach and the drivers considered may be necessary. For example, we limited anthropogenic drivers to fishing only, since fishing has been recognized as the predominant factor influencing ecosystem dynamics on a global scale (e.g. Jackson et al. 2001, Pauly et al. 2002). While fishing was clearly influential across ecosystems, on a regional scale, other anthropogenic impacts, such as coastal development and urbanization, pollution or other human uses, should be included as drivers when appropriate for regional EBFM applications, along with any additional ecosystem response indicators appropriate to these drivers.

Finally, this work again shows the importance of developing and maintaining time series for EBFM related not just to fished species but to their key predators and prey and to key environmental drivers that are relevant to each ecosystem. Our convincing empirical evidence for the importance of the triad of drivers to fishery production is based on the longterm scientific monitoring efforts of multiple agencies and institutions across a variety of regions. However, even with this data set it was difficult to explain 
some proposed universal ecosystem indicators such as trophic level of the community because time series on zooplankton and apex predators were not available in all ecosystems. For EBFM to be successful, maintenance of current ecological data sets is critical. In addition, as key ecosystem indicators are identified, testing the relationships between these indicators and available driving time series may identify new monitoring necessary to support EBFM.

\section{CONCLUSIONS}

It is crucial to search for empirical correlations between ecosystem indicators and drivers in the process of EBFM where appropriate indicators have to be selected and applied rigorously, although doing so has largely been neglected (Daan 2005). Through PLS regression modeling of the relationships between ecosystem indicators and the triad of fisheries, trophodynamic and environmental drivers, we identified common themes shared by all the ecosystems studied in terms of the relative importance of the triad of drivers. These common themes were: (1) environmental drivers, particularly temperature-related independent indicators (e.g. SST), affected all systems, as found by Bundy et al. (2012), and were most related to one of 3 biomass indicators; (2) trophodynamic drivers were related to measures of biotic community structure; (3) the fisheries drivers (as would be expected) tended to be most related to the catch-based indicators, yet had no impact on total system biomass in 4 out of the 9 ecosystems. These results suggest that a suite of both standardized and ecosystem-specific indicators are be needed to reflect the different impacts from fisheries, trophodynamic and environmental drivers regardless of the ecosystem being investigated.

Acknowledgements. We are grateful to 2 anonymous reviewers and editors (Dr. Tom Miller and others) for constructive reviews of previous drafts of this paper. We thank $\mathrm{H}$. Benoit of Fisheries and Oceans Canada (DFO) for providing biomass and catch data for the Gulf of St. Lawrence. This collaborative, multilateral work was funded through the US Comparative Analysis of Marine Ecosystem Organization (CAMEO), the Norwegian Research Council (NRC) and Canada's Ecosystem Research Initiative (ERI). Major national institutes (DFO, Institute for Marine Research of Norway, and National Marine Fisheries Service of the USA) also contributed significant in-kind and directed resources to this project. This work is also endorsed by Ecosystem Studies of Sub-Arctic Seas (ESSAS). The work we report upon herein resulted from several joint meetings, particularly the Surplus Production Modeling Workshop (SPMW 1 \& 2) and associated intercessional efforts, which represent a continuation of and follow-on to other joint workshops, including Canadian and US Ecosystems (CANUSE I \& II), Marine Ecosystems of Norway and the US (MENU I \& II), and Norwegian-Canadian Collaborations (NORCAN). Finally, we dedicate this work to the memory of Bern Megrey, who was an integral part of these efforts and whose untimely death was unfortunate but whose enthusiasm for this work was invaluable.

\section{LITERATURE CITED}

Behrenfeld MJ, Falkowski PG (1997) Photosynthetic rates derived from satellite-based chlorophyll concentration. Limnol Oceanogr 42:1-20

Beverton RJH, Holt SJ (1957) On the dynamics of exploited fish populations. Chapman \& Hall, London

Blanchard JL, Dulvy NK, Jennings S, Ellis JR, Pinnegar JK, Tidd A, Kell LT (2005) Do climate and fishing influence size-based indicators of Celtic Sea fish community structure? ICES J Mar Sci 62:405-411

Blanchard JL, Coll M, Trenkel VM, Vergnon RM and others (2010) Trend analysis of indicators: a comparison of recent changes in the status of marine ecosystems around the world. ICES J Mar Sci 67:732-744

Bundy A, Fanning P, Zwanenburg KCT (2005) Balancing exploitation and conservation of the eastern Scotian Shelf ecosystem: application of a 4D ecosystem exploitation index. ICES J Mar Sci 62:503-510

Bundy A, Heymans JJ, Morissette L, Savenkoff C (2009) Seals, cod and forage fish: a comparative exploration of variations in the theme of stock collapse and ecosystem change in four Northwest Atlantic ecosystems. Prog Oceanogr 81:188-206

Bundy A, Bohaboy EC, Hjermann DO, Mueter FJ, Fu C, Link JS (2012) Common patterns, common drivers: comparative analysis of aggregate surplus production across ecosystems. Mar Ecol Prog Ser 459:203-218

> Carrascal LM, Galván L, Gordo O (2009) Partial least squares regression as an alternative to current regression methods used in ecology. Oikos 118:681-690

> Chassot E, Melin F, Le Pape O, Gascuel D (2007) Bottom-up control regulates fisheries production at the scale of ecoregions in European seas. Mar Ecol Prog Ser 343:45-55

Christensen V (2000) Indicators for marine ecosystems affected by fisheries. Mar Freshw Res 51:447-450

> Christensen V, Walters C (2004) Ecopath with Ecosim: methods, capabilities and limitations. Ecol Model 172:109-139

> Coll M, Shannon LJ, Moloney CL, Palomera I, Tudela S (2006) Comparing trophic flows and fishing impacts of a NW Mediterranean ecosystem with coastal upwellings by means of standardized ecological models and indicators. Ecol Model 198:53-70

Coll M, Shannon LJ, Yemane D, Link JS and others (2010) Ranking the ecological relative status of exploited marine ecosystems. ICES J Mar Sci 67:769-786

> Cury PM, Christensen V (2005) Quantitative ecosystem indicators for fisheries management. ICES J Mar Sci 62: $307-310$

> Daan N (2005) An afterthought: ecosystem metrics and pressure indicators. ICES J Mar Sci 62:612-613

Ecosystem Assessment Program (2009) Ecosystem assessment report for the Northeast US Continental Shelf large marine ecosystem. US Dep Comm, NE Fish Sci Cent Ref Doc 09-11. NOAA Fish Natl Mar Fish Serv, Woods Hole, MA. www.nefsc.noaa.gov/publications/crd/crd0911/crd 0911.pdf 
Friedland KD, Stock C, Drinkwater KF, Link JS and others (2012) Pathways between primary production and fisheries yields of large marine ecosystems. PLoS ONE 7: e28945

Froese F, Pauly D (2011) FishBase. www.fishbase.org (accessed 24 Apr 2011)

Fulton EA, Smith ADM, Punt AE (2005) Which ecological indicators can robustly detect effects of fishing? ICES J Mar Sci 62:540-551

Hare SR, Mantua NJ (2000) Empirical evidence for North Pacific regime shifts in 1977 and 1989. Prog Oceanogr 47: 103-145

Holst JC, Dragesund O, Hamre J, Misund OA, Østvedt OJ (2002) Fifty years of herring migrations in the Norwegian Sea. ICES Mar Sci Symp 215:352-360

Jackson JBC, Kirby MX, Berger WH, Bjorndal KA and others (2001) Historical overfishing and the recent collapse of coastal ecosystems. Science 293:629-637

Jennings S (2005) Indicators to support an ecosystem approach to fisheries. Fish Fish 6:212-232

Libralato S, Coll M, Tudela S, Palomera I, Pranovi F (2008) Novel index for quantification of ecosystem effects of fisheries as removal of secondary production. Mar Ecol Prog Ser 355:107-129

Link JS (2005) Translating ecosystem indicators into decision criteria. ICES J Mar Sci 62:569-576

Link JS (2010) Ecosystem-based fisheries management: confronting tradeoffs. Cambridge University Press, Cambridge

Link JS, Megrey BA, Miller TJ, Essington T and others (2010a) Comparative analysis of marine ecosystems: international production modelling workshop. Biol Lett 6:723-726

Link JS, Yemane D, Shannon LJ, Coll M and others (2010b) Relating marine ecosystem indicators to fishing and environmental drivers: an elucidation of contrasting responses. ICES J Mar Sci 67:787-795

Link JS, Gaichas S, Miller TJ, Essington T and others (2012) Synthesizing lessons learned from comparing fisheries production in 13 northern hemisphere ecosystems: emergent fundamental features. Mar Ecol Prog Ser 459: 293-302

NRC (National Research Council) (2000) Ecological indicators for the nation. National Academy Press, Washington, DC

Ojaveer H, Eero M (2011) Methodological challenges in assessing the environmental status of a marine ecosystem: case study of the Baltic Sea. PLoS ONE 6:e19231

Pauly D, Christensen V (1995) Primary production required to sustain global fisheries. Nature 374:255-257

Pauly D, Watson R (2005) Background and interpretation of the 'Marine Trophic Index' as a measure of biodiversity. Phil Trans R Soc B 360:415-423

Pauly D, Christensen V, Guénette S, Pitcher TJ and others (2002) Towards sustainability in world fisheries. Nature 418:689-695

> Piet GJ, Jansen HM, Rochet MJ (2008) Evaluating potential indicators for an ecosystem approach to fishery management in European waters. ICES J Mar Sci 65:1449-1455

Pikitch EK, Santora C, Babcock EA, Bakun A and others (2004) Ecosystem-based fishery management. Science
305:346-347

R Development Core Team (2011) R: a language and environment for statistical computing. R Foundation for Statistical Computing, Vienna. www.R-project.org/

Rice JC, Rochet MJ (2005) A framework for selecting a suite of indicators for fisheries management. ICES J Mar Sci 62:516-527

Scheffer M, Carpenter R (2003) Catastrophic regime shifts in ecosystems: linking theory to observation. Trends Ecol Evol 18:648-656

Shannon LJ, Coll M, Yemane D, Jouffre D and others (2010) Comparing data-based indicators across upwelling and comparable systems for communicating ecosystem states and trends. ICES J Mar Sci 67:807-832

Sherman K, Belkin IM, Friedland KD, O'Reilly J, Hyde K (2009) Accelerated warming and emergent trends in fisheries biomass yields of the world's large marine ecosystems. Ambio 38:215-224

Shin YJ, Shannon LJ (2010) Using indicators for evaluating, comparing and communicating the ecological status of exploited marine ecosystems. 1. The IndiSeas project. ICES J Mar Sci 67:686-691

> Shin YJ, Bundy A, Shannon LJ, Simier M and others (2010a) Can simple be useful and reliable? Using ecological indicators to represent and compare the states of marine ecosystems. ICES J Mar Sci 67:717-731

Shin YJ, Shannon LJ, Bundy A, Coll M and others (2010b) Using indicators for evaluating, comparing, and communicating the ecological status of exploited marine ecosystems. 2. Setting the scene. ICES J Mar Sci 67:692-716

Sissenwine M, Murawski S (2004) Moving beyond 'intelligent thinking': advancing an ecosystem approach to fisheries. Mar Ecol Prog Ser 274:291-295

Skud BE (1975) Revised estimates of halibut abundance and the Thompson-Burkenroad debate. Int Pac Halibut Comm Sci Rep No. 56. Int Pac Halibut Comm, Seattle, WA. www. iphc.int/publications/scirep/SciReport0056.pdf

Steele JH (2004) Regime shifts in the ocean: reconciling observations and theory. Prog Oceanogr 60:135-141

> Travers M, Shin YJ, Shannon L, Cury P (2006) Simulating and testing the sensitivity of ecosystem-based indicators to fishing in the southern Benguela ecosystem. Can J Fish Aquat Sci 63:943-956

Tudela S, Coll M, Palomera I (2005) Developing an operational reference framework for fisheries management based on a two dimensional index on ecosystem impact. ICES J Mar Sci 62:585-591

Ware DM, Thomson RE (2005) Bottom-up ecosystem trophic dynamics determine fish production in the Northeast Pacific. Science 308:1280-1284

> Wells BK, Grimes CB, Sneva JG, McPherson S, Waldvogel JB (2008) Relationships between oceanic conditions and growth of Chinook salmon (Oncorhynchus tshawytscha) from California, Washington, and Alaska, USA. Fish Oceanogr 17:101-125

Wold S, Sjöström M, Eriksson L (2001) PLS-regression: a basic tool of chemometrics. Chemom Intell Lab Syst 58:109-130

Zador S (2011) Ecosystem considerations for 2012. North Pac Fish Manag Counc, Anchorage, AK. http://access.afsc. noaa.gov/reem/ecoweb/Eco2011.pdf 